\title{
Micronutrient cofactor research with extensions to applications
}

\author{
Donald B. McCormick \\ Department of Biochemistry and Program in Nutrition and Health Sciences, Emory \\ University, Atlanta, GA 30322-3050, USA
}

Following identification of essential micronutrients, there has been a continuum of research aimed at revealing their absorption, transport, utilization as cofactors, and excretion and secretion. Among those cases that have received our attention are vitamin $\mathrm{B}_{6}$, riboflavin, biotin, lipoate, ascorbate, and certain metal ions. Circulatory transport and cellular uptake of the water-soluble vitamins exhibit relative specificity and facilitated mechanisms at physiological concentrations. Isolation of enzymes and metabolites from micro-organisms and mammals has provided information on pathways involved in cofactor formation and metabolism. Kinases catalysing phosphorylation of $\mathrm{B}_{6}$ and riboflavin have a preference for $\mathrm{Zn}^{2+}$ in stereospecific chelates with adenosine triphosphate. The synthetase for flavin adenine dinucleotide prefers $\mathrm{Mg}^{2+}$. The flavin mononucleotidedependent oxidase that converts the $5^{\prime}$-phosphates of pyridoxine and of pyridoxamine to pyridoxal phosphate is a connection between $\mathrm{B}_{6}$ and riboflavin and is a primary control point for conversion of $\mathrm{B}_{6}$ to its coenzyme. Sequencing and cloning of a side-chain oxidase for riboflavin was achieved. Details on binding and function have been delineated for some cofactor systems, especially in several flavoproteins. There is both photochemical oxidation and oxidative catabolism of $\mathrm{B}_{6}$ and riboflavin. Both biotin and lipoate undergo oxidation of their acid side chains with redox cleavage of the rings. Applications from our findings include the development of affinity absorbents, enhanced drug delivery, delineation of residues in biopolymer modification, pathogen photoinactivation in blood components, and input into human dietary recommendations. Ongoing and future research in the cofactor arena can be expected to add to this panoply. At the molecular level, the way in which the same cofactor can participate in diverse catalytic reactions resides in interactions with surrounding enzyme structures that must be determined case by case. At the level of human intake, more knowledge is desirable for making micronutrient recommendations based on biochemical indicators, especially for the span between infancy and adulthood.

Micronutrient cofactors: Vitamins: Metabolic pathways: Enzymes

Corresponding author: Dr Donald B. McCormick, fax +1 770938 2215, email biocdbm@emory.edu 


\section{Introduction}

The subject of micronutrient cofactors is of major importance because the vitamins and trace elements that constitute this group of dietary ingredients are essential in their function to help man and other organisms utilize such macronutrients as proteins, carbohydrates, fats, and macrominerals that provide energy and the major substances of our bodies.

It should be noted for the reader who has an interest in micronutrient cofactors that there are timely books dealing with nutritional biochemistry of the vitamins (Bender, 1992), the history as well as particulars of conversions of vitamins to coenzymes and other biologically active forms (Combs, 1998), and sources that provide coverage of each vitamin-coenzyme group (McCormick et al. 1997b; Rucker et al. 2001). There are also periodic symposia resulting in volumes on the updated findings for most of the cofactor groups. This too is the case with ongoing volumes of 'Metal ions in biological systems', first appearing 28 years ago (Sigel, 1974). Again symposia and conferences on specific metal ion cofactors add to the published detail available to the professional.

Given the invitation to write 'a reflective personal review', the author has taken the opportunity to attempt to condense most of his scientific perambulations on micronutrient research into a synoptic treatise. The satisfaction derived from discovery has been enhanced by applications that serve more than to catalogue basic knowledge, so such extensions are also briefly covered in the present review. A more specific acknowledgement of the help provided by mentors, trainees, and other colleagues in a somewhat wider venue of biochemical and nutritional research has been published (McCormick, 2000), so this account will be a more circumscribed focus on findings and applications relating to those micronutrient cofactors that have received our specific attention.

\section{Uptake, transport, and storage of water-soluble vitamins}

Although there are differences in the ways that cells take in and route the structurally dissimilar water-soluble vitamins, findings from a number of laboratories indicate commonality of relative specificity and facilitated uptake at physiological concentrations, with passive diffusion becoming predominant at pharmacological levels. Circulatory, less-specific binding proteins help vector the vitamins to organ sites in mammals, which also have pregnancy-induced carriers in some cases. The latter have some parallel in the specific, tight-binding proteins that permit storage of such vitamins as riboflavin and biotin in the eggs of birds. Our studies in this subject area are summarized in the following two sections.

\section{Uptake}

The entry of pyridoxine into liver cells is insensitive to $\mathrm{Na}^{+}$(and hence $\mathrm{Na}^{+} / \mathrm{K}^{+}$ATPase) and dependent on metabolic trapping by pyridoxal kinase (Kozik \& McCormick, 1984), whereas uptake by renal proximal tubular cells is similar but may involve $\mathrm{Na}^{+} / \mathrm{H}^{+}$exchange and/or $\mathrm{pH}$ gradient effects (Bowman \& McCormick, 1987, 1989; McCormick, 1989). Disposition of $\mathrm{B}_{6}$ glucosides was shown to depend upon uptake as well as subsequent metabolic events (Joseph $e t$ al. 1996; Zhang et al. 1993a). Hepatocyte uptake of riboflavin, which is carrier-mediated but not $\mathrm{Na}^{+}$-dependent and involves flavokinase-catalysed phosphorylation (Aw et al. 1983), has been contrasted with gut (enterocyte) absorption and with uptake by proximal tubular renal cells (Bowman et al. 1989). Biotin entry depends on ligandin (glutathione S-transferase) as typical for organic acid anions (Bowers-Komro \& McCormick, 1985b). 
Transport and storage

Both physical (Pritchard et al. 1967) and biological (Lee et al. 1973b) interactions of biotin with avidin were investigated, as was specificity of avidin (Zempleni et al. 1996e) and biocytinase (McCormick, 1969). We have delineated properties of the avian carrier and storage proteins for riboflavin (Froehlich et al. 1980) including its flavin-binding specificity (Choi \& McCormick, 1980), were the first to recognize the pregnancy-induced riboflavin-carrier protein in a mammal (Merrill et al. 1979a), and elaborated on the occurrence of other cytosolic binding proteins for this vitamin (Merrill et al. 1982). Further work has led to the identification of immunoglobulin carriers in man (Merrill et al. 1981a; Innis et al. 1985, 1986).

\section{Vitamin metabolism}

Some of the more recent and interesting advances in research on water-soluble vitamins has to do with their biosyntheses. In the past few years, the missing intermediates and enzymes in the pathways for formation of pyridoxine, riboflavin, and biotin have been discovered. Biosynthesis of $\mathrm{B}_{6}$ in Escherichia coli $\mathrm{K}-12$ has been shown to involve condensation of 4-phospho-hydroxyL-threonine with 1-deoxy-D-xylulose 5-phosphate to form pyridoxine 5'-phosphate (Winkler, 2000). For riboflavin (Bacher et al. 2000) the beginning precursor is GTP, which, after four steps, is converted to 5-amino-6-ribitylamino- $2,4(1 \mathrm{H}, 3 \mathrm{H})$-pyrimidinedione. This latter reacts with 3,4-dihydroxybutanone 4-phosphate to form 6,7-dimethyl-8-ribityllumazine, which then dismutates into riboflavin. Enzymes responsible for catalysing the half-dozen steps, including the synthases for lumazine and riboflavin, have been isolated and characterized. In the case of biotin, the terminal metal ion-containing synthases that operate to form dethiobiotin (Schneider \& Lindqvist, 1997) and biotin (Flint \& Allen, 1997) have been examined. Other studies have centred on the conversions of such vitamins to their coenzymic operating forms and their eventual catabolism. The following four sections outline some of our findings.

\section{Vitamin $B_{6}$}

Pyridoxal (pyridoxine, pyridoxamine) kinase. Isolation of and comparative studies on both proand eucaryotic forms of pyridoxal kinase allowed us to delineate general properties, including the first substantiated role of $\mathrm{Zn}^{2+}$ in preference to $\mathrm{Mg}^{2+}$ as the cosubstrate ATP complex for the mammalian phosphokinase (McCormick et al. 1961), and led to circumscription of inhibitory aspects (McCormick \& Snell, 1961), including the potent action of carbonyl reagents (McCormick \& Snell, 1959; McCormick et al. 1960) and such drugs are known to bind to the kinase (McCormick \& Chen, 1999).

Pyridoxine (pyridoxamine) 5'-phosphate oxidase. We succeeded in the first complete purification of pyridoxine (pyridoxamine) 5'-phosphate oxidase, the FMN-dependent enzyme responsible for conversion of the kinase-derived phosphovitamin $\mathrm{B}_{6}$ to coenzymic pyridoxal 5'-phosphate (Kazarinoff \& McCormick, 1975). More facile affinity purification (Bowers-Komro et al. 1986) and assays (DePecol \& McCormick, 1980) were developed and structural requirements for substrate (Kazarinoff \& McCormick, 1973, 1975; DePecol \& McCormick, 1980; Merrill et al. 1980; Bowers-Komro \& McCormick, 1987) and coenzyme specificities (Kazarinoff \& McCormick, 
1974; Merrill et al. 1979b) accomplished. The oxidase requires the 5'-phosphate for substrate but is fairly tolerant of substitutions on the 4-aminomethyl function. Systematic elucidation of the dimeric subunit association (Horiike et al. 1979a; Tsuge \& McCormick, 1980), active-site amino acid residues (McCormick et al. 1976; Horiike et al. 1979b; Tsuge \& McCormick, 1980; Choi \& McCormick, 1981; Bowers-Komro et al. 1986), kinetics of which are somewhat different for the two natural substrates (Choi et al. 1982, 1983), and ultimately mechanistic delineation of stereochemical aspects (Bowers-Komro \& McCormick, 1984b, 1985a; McCormick \& Bowers-Komro, 1986) have provided definitive information on the way this essential flavoprotein operates in the ionic abstraction of a substrate hydrogen (Bowers-Komro \& McCormick, 1984a), which depends upon the flavin status of an organism (Rasmussen et al. 1979, 1980), and participates in the regulation of $\mathrm{B}_{6}$ metabolism (Merrill et al. 1978b; McCormick \& Merrill, 1980). The sequences for this essential oxidase from several organisms have been determined (McCormick \& Chen, 1999). An important interface between vitamins $\mathrm{B}_{2}$ and $\mathrm{B}_{6}$ is now clear.

The scheme given in Fig. 1 outlines the sequential roles of kinase and oxidase in the interconversions of $\mathrm{B}_{6}$ vitamers toward the coenzyme pyridoxal 5'-phosphate.

\section{Riboflavin}

Flavokinase. The enzyme responsible for catalysing phosphorylation of riboflavin to form riboflavin 5 '-phosphate (FMN) in mammalian tissue and elsewhere was shown by us to be flavokinase, which is another $\mathrm{Zn}^{2+}$-preferring enzyme (McCormick, 1962; Merrill \& McCormick, 1980; Nakano \& McCormick, 1991b). Its enrichment from liver was accomplished by classic techniques (McCormick, 1962) and then purification done with affinity chromatography (Arsenis \& McCormick, 1964a; Merrill \& McCormick, 1980; Nakano \& McCormick, 1991a). Detailed studies on the specificity of this enzyme (McCormick \& Butler, 1962; McCormick et al. 1963, 1964; Yang et al. 1964; Chassy et al. 1965) helped clarify the biological activities of

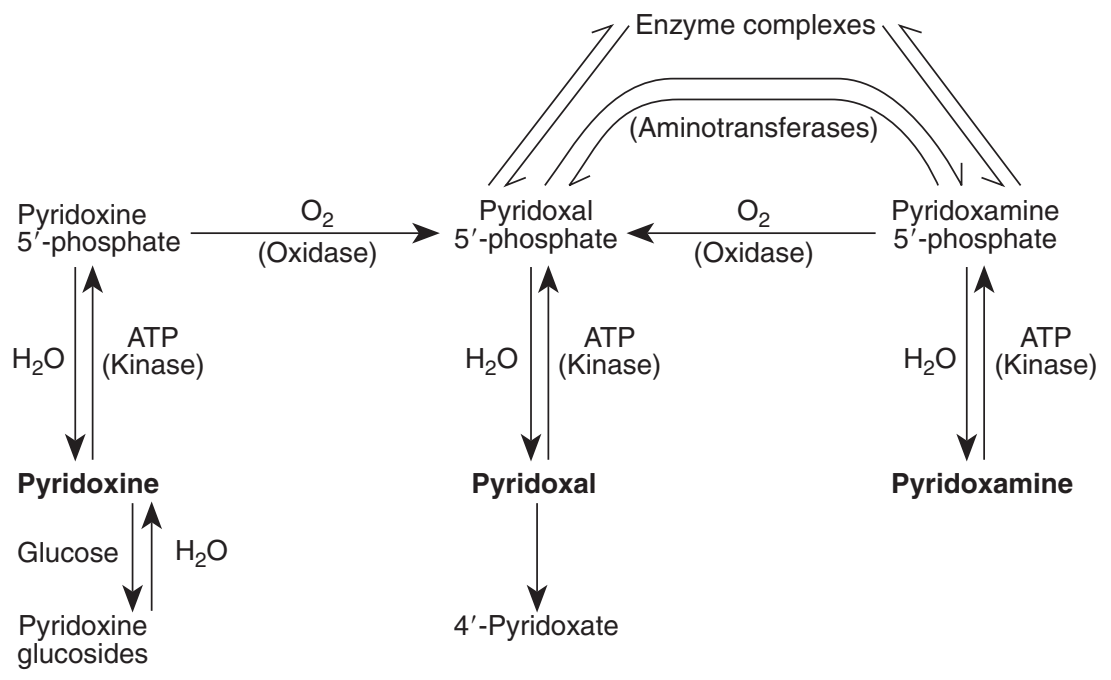

Fig. 1. Vitamin $B_{6}$ metabolism. Reactions shown occur in numerous organisms and organs, especially the liver. For the disposition of ingested forms of $B_{6}$ with an indication of organ interplay, see McCormick (2001). Both kinase and oxidase are cytosolic. 
flavin analogues. Investigations of substrate induction (Merrill et al. 1978a; Lee \& McCormick, 1983 ) and thyroid hormone stimulation (McCormick et al. 1984; Lee \& McCormick, 1985) led to recognition of the 'active' and 'inactive' forms, which are poised at the regulation site for the biosynthesis of the flavocoenzymes FMN and FAD.

FAD synthetase. We elaborated the substrate specificity of mammalian FAD synthetase (McCormick, 1964a,b; Bowers-Komro et al. 1989; McCormick et al. 1997a) and accomplished its partial (Gomes \& McCormick, 1983) and then complete purification using FMN-agarose (Kazarinoff et al. 1975; Oka \& McCormick, 1987). Further work on this $\mathrm{Mg}^{2+}$-preferring enzyme led to more detailed characterization of the cooperatively interactive kinase-synthetase system and to the kinetic order as regards substrate addition and product removal (Yamada et al. 1990).

FMN phosphatase and FAD pyrophosphatase. The interfering, non-specific actions of acid and alkaline phosphatases (McCormick, 1961; McCormick \& Russell, 1962) and FAD pyrophosphatase have been separated and generally characterized as degradative hydrolases responsible for breakdown of flavocoenzymes (Lee \& McCormick, 1983).

Riboflavin side-chain oxidases. A bacterial ribityl side-chain oxidizing enzyme that had been called a 'hydrolase' was found by us to have relative specificity (Yang \& McCormick, 1967a), whereas another enzyme narrowly specific for riboflavin (Kekelidze et al. 1994, 1995) has been molecularly cloned and sequenced from a fungal organism (Chen \& McCormick, 1997a) and found to form both aldehyde and acid 'schizoflavin' products at the 5'-terminus (Chen \& McCormick, 1997b).

Flavin metabolites and analogues. We have helped detail the overall metabolic fate of riboflavin (Foley et al. 1967; Yang \& McCormick, 1967b; McCormick, 1975b, 1976a; McCormick et al. 1984, 1988; Oka \& McCormick, 1985; Chastain \& McCormick, 1987a, b, 1988; Roughead \& McCormick, 1991), 8 $\alpha$-amino acid flavins derived from covalent forms (Addison \& McCormick, 1978; Chia et al. 1978), and flavin analogues (Ogunmodede \& McCormick, 1966; Tu \& McCormick, 1969) in the mammal and in milk from cows (Roughead \& McCormick, 1990a) and in human milk (Roughead \& McCormick, 1990b). The finding that an $8 \alpha$-sulfonyl-riboflavin appears in human urine as a result of catabolic turnover of monoamine oxidase is noteworthy (Chastain \& McCormick, 1987b). The predominant catabolite of riboflavin to appear in blood plasma following ingestion of the vitamin is the $7 \alpha$-hydroxy compound (Zempleni et al. 1996a,b). The in vivo kinetics of riboflavin absorption and disposition have been quantified in normal human subjects (Zempleni et al. 1996a) and in women with liver cirrhosis ( Zempleni et al. 1996c).

The scheme given in Fig. 2 outlines central aspects of riboflavin transport, metabolism, utilization, and excretion.

\section{Biotin}

Biosynthesis. Proof that biotin is formed directly from dethiobiotin was accomplished by our use of the radiolabelled precursor of the vitamin (Tepper et al. 1966; Li et al. 1968a). 


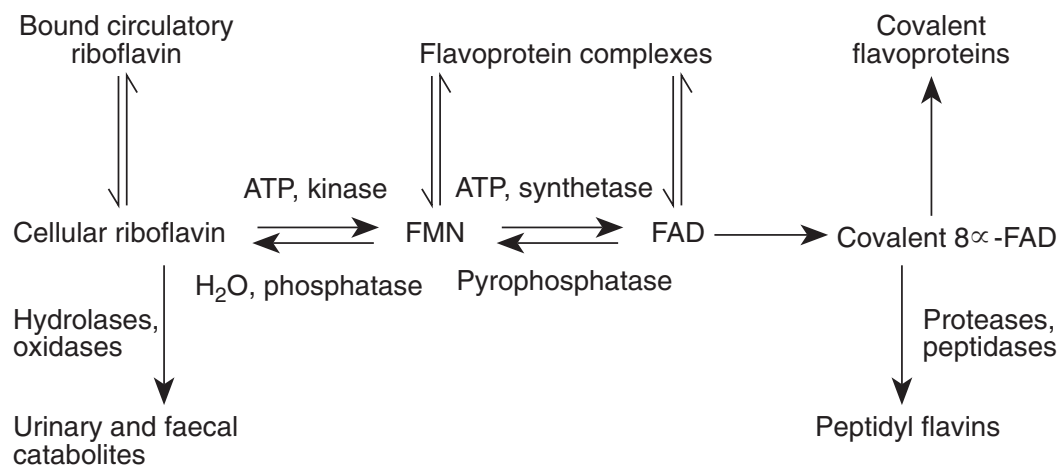

Fig. 2. Riboflavin metabolism. Biosynthesis and turnover of flavocoenzymes occur in most cells, with kinase and synthetase located in the cytosol but degradative enzymes included within organelles.

Catabolism. The fate of biotin and some of its analogues when wholly degraded in a pseudomonad (Brady et al. 1965, 1966; Ruis et al. 1968; Iwahara et al. 1969; Im et al. 1970, 1973; Roth et al. 1970; Kazarinoff et al. 1972; Westendorf \& McCormick, 1980) and partly degraded in a fungus (Li et al. 1968b) and the rat (Lee et al. 1972, 1973a) was elaborated in our laboratory. Also a discriminating colorimetric reaction for biotin and analogues was developed (McCormick \& Roth, 1970). Present knowledge of the metabolism of biotin is based on these detailed studies (McCormick \& Wright, 1970; McCormick, 1975a, 1976b; McCormick \& Olson, 1984). Whereas a soil pseudomonad forced to use biotin as the sole source of C, N, S and energy can effect extensive degradation of the vitamin, including the bicyclic ring system, mammals, including man (Zempleni et al. 1996d), operate more sparingly, mainly on sidechain $\beta$-oxidation and oxidation of the ring $S$.

Based on the numerous catabolites we have isolated and structurally identified and the known function of $\varepsilon$-lysyl-linked biotin in mammalian carboxylases, an overview of events is summarized in Fig. 3.

\section{Lipoate}

Similar studies have been conducted on the catabolic fate of lipoate, an essential cofactor that is covalently linked to the $\varepsilon$-amino functions of specific lysyl residues of transacylases. Lipoate is a vitamin for some microbes but not the mammal, which can biosynthesize it from the level of octanoate. We first detailed total degradation of lipoate in a pseudomonad isolated by enrich-

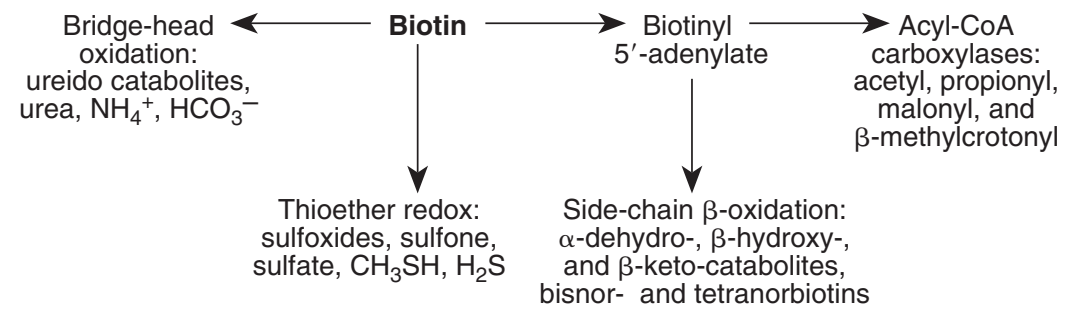

Fig. 3. Biotin metabolism. Though side-chain $\beta$-oxidation and $\mathrm{S}$ oxidation occur in bacteria and mammals, extensive degradation of the bicyclic ring system is known to occur only in certain bacteria. 
ment culture from soil (Shih et al. 1972, 1975; Chang et al. 1975; Furr et al. 1978; Furr \& McCormick, 1978), and then in the rat (Harrison \& McCormick, 1974; Spence \& McCormick, 1976). Syntheses and delineation of the properties of critical side-chain-shortened catabolites, for example bisnor- and tetranorlipoates, were also accomplished (Shih et al. 1974) as were HPLC chromatographic separations of metabolites (Howard \& McCormick, 1981).

The routes for function and catabolism of lipoate are shown in Fig. 4.

\section{Flavocoenzyme function}

To better understand the nature of flavocoenzymes, namely FMN and both non-covalently bound FAD and the less frequent but critical $8 \alpha$-linked FAD cases, we have examined complexes of free flavins and those that were associated with those specific proteins that serve as binding proteins or flavin enzymes. Some findings are mentioned in the next two sections.

\section{Inter- and intramolecular flavin complexes}

Our studies on the nature of inter- and intramolecular complexes of flavins with purines and pyrimidines (Chassy \& McCormick, 1965a; Tsibris et al. 1965; Roth \& McCormick, 1967; McCormick, 1968a) including synthetic analogues of FAD helped elucidate the strength and types of interactions involved, particularly with FAD wherein the adenine moiety quenches the fluorescence of the isoalloxazine ring. Extension of such studies to flavin-aromatic amino acid systems (Föry et al. 1968, 1970a,b; MacKenzie et al. 1969; McCormick, 1970, 1977b; Wu \& McCormick, 1971a,b; Johnson \& McCormick, 1973; Johnson et al. 1975; McCormick et al. 1975; Getoff et al. 1978) and ultimately to flavoproteins (McCormick, 1970, 1977a,b; McCormick \& Tu, 1970; Wu et al. 1970; Tu \& McCormick, 1973, 1974; Shiga et al. 1975; Merrill et al. 1981b) secured the expectation that such interactions are common, particularly with tryptophanyl and tyrosyl residues, and often account for part of the facilitated binding of flavins to proteins.

\section{Flavin-dependent enzymes}

The specificity of coenzyme binding and function (Arsenis \& McCormick, 1964b; McCormick et al. 1964; Chassy \& McCormick, 1965b; Roth et al. 1966; Tsibris et al. 1966; Merrill et al. 1979b; Visser et al. 1968), nature of active-site residues (McCormick et al. 1967; Koster et al. 1968; McCormick, 1970; Wu et al. 1970; Tu \& McCormick, 1973, 1974; Falk et al. 1976; Falk

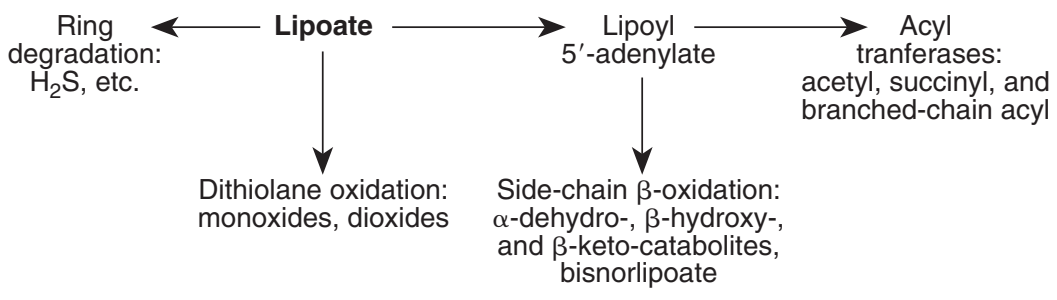

Fig. 4. Lipoate metabolism. More extensive degradation of the dithiolane ring occurs in bacteria utilizing lipoate as a sole source of $S$ and $C$ than in mammals. 
\& McCormick, 1976; Horiike et al. 1979b; Choi \& McCormick, 1981) and physical properties of several flavin-dependent enzymes have been elucidated. One common feature is the binding of the pyrimidinoid portion of the isoalloxazine system of FMN within a cleft, which often allows projection of the dimethylbenzenoid edge toward solvent. A prototypic example of using a coenzyme as a photochemical probe for the active site of an enzyme was provided by our work with FAD in D-amino acid oxidase, wherein a tyrosyl as well as lysyl and cysteinyl residues were proven critical (Tu \& McCormick, 1973). The stereochemical effects of $8 \alpha$-flavin linkage to a cysteinyl residue in monoamine oxidase were confirmed and quantified by our synthesis of the active-site portion of this enzyme (Falk et al. 1976; Falk \& McCormick, 1976).

\section{Metal ions}

We have shown the involvement of $\mathrm{K}^{+}$as an activator and $\mathrm{Zn}^{2+}$ chelated with ATP as cosubstrate with pyridoxal kinase (McCormick et al. 1961). Also the preference for $\mathrm{Zn}^{2+}$ was established for flavokinase (McCormick, 1962; Merrill \& McCormick, 1980) and bacterial dihydro-orotase (Sander et al. 1965). The metal ion liganding properties of several important functional groups (Griesser et al. 1971) including amino acids (Griesser et al. 1969; McCormick et al. 1969, 1974; Sigel et al. 1969a,b, 1970, 1972, 1977; Sigel \& McCormick, 1971, 1974; Walker et al. 1972), nucleotides (Sigel et al. 1967; Sigel \& McCormick, 1974), and such vitamins as biotin (Sigel et al. 1969c, 1978a; Griesser et al. 1970, 1973; Sigel \& McCormick, 1974) and lipoate (Sigel et al. 1978a,b) have been delineated for important cations of the Irving-Williams series. These latter studies extend our knowledge of the possible interactions within biological metal ion-containing systems.

\section{Derived applications}

In biomedical sciences, most investigations are based (and funded) on the expectation that findings will not only shed light on questions of a basic nature but also eventually lead to applications that will directly or indirectly improve the lot of mankind. Over the span of our research, several extensions of the basic findings have led to useful applications. Though few such discoveries nowadays are the result of only one individual or group, at least a significant and literature-documented role has been played by my colleagues and me in the following.

\section{Biochemically specific ('affinity') absorbents}

Our numerous studies on the specificity of biopolymers (enzymes, binding-proteins, and polynucleotides) led me to realize nearly a half century ago that one could take advantage of the selective binding of a biopolymer to its substrate, cofactor, or complementary polynucleotide by synthesizing biochemically specific absorbents. A start in this direction was my synthesis in 1959 of the one-methylene-extended homologue of pyridoxal with the intent of coupling this to some matrix for the column purification of pyridoxal kinase. This was elaborated, well before the current term of 'affinity chromatography', with several examples that first used derivatized cellulose, for example liver flavokinase on flavin-cellulose (Arsenis \& McCormick, 1964a), avidin on biotinyl-cellulose (McCormick, 1965), some FMN-dependent enzymes on FMN-cellulose (Arsenis \& McCormick, 1966), and polyA nucleotides on thymidy- 
late-cellulose (Sander et al. 1966). As Sephadex gained widespread use in enzymology, we turned to this more manageable material for a matrix, often with linker arms to make an 'affinose'. Examples include riboflavin-binding proteins on flavinyl-affinose (Merrill \& McCormick, 1978), pregnancy-specific riboflavin-binding protein on flavinyl-affinose (Merrill et al. 1979a), liver flavokinase on flavinyl-affinose (Merrill \& McCormick, 1980), pyridoxine (pyridoxamine) 5'-phosphate oxidase on 5'-phosphopyridoxyl-affinose (Bowers-Komro et al. 1986), FAD synthetase on FMN-affinose (Oka \& McCormick, 1987; McCormick et al. 1997a,b), $\mathrm{B}_{6}$-binding proteins on pyridoxyl-affinose (McCormick et al. 1991), and brain flavokinase on flavinyl-affinose (Nakano \& McCormick, 1991a). The generalized scheme for formation and use of affinity absorbents is illustrated in Fig. 5.

We also have immobilized enzymes as a means for flow-through catalysis. Examples are with D-amino oxidase (Tu \& McCormick, 1972) and flavokinase (Merrill \& McCormick, 1979).

\section{Drug delivery}

Information from our studies on the specificity of transporters for the vitamins coupled with our knowledge of the enzymic events that occur upon their entry into cells led to the design of vitamin analogue models that exemplify transporter-enhanced delivery of bioactive compounds. A specific case elaborated is the chemical attachment of bioactive amines to vitamin $\mathrm{B}_{6}$ so as to be 'piggybacked' through the $\mathrm{B}_{6}$ transporter and metabolically released inside kidney or liver cells as free amine plus the coenzyme pyridoxal 5'-phosphate (Zhang \& McCormick, 1991, 1992a,b; Zhang et al. 1993b; McCormick, 1994). A means by which some less-transportable compounds of therapeutic use can be imported into cells is exemplified in Fig. 6.

\section{Biopolymer modifications}

We established the theoretical bases, including means for calculating number of residues modified and ways to plot correctly such data, in part, to clarify the erroneous manner in which such data had sometimes been published by others. This work (Horiike \& McCormick, 1979, 1980) can be extended to experimental protocols for chemical (McCormick, 1970; Horiike et al.

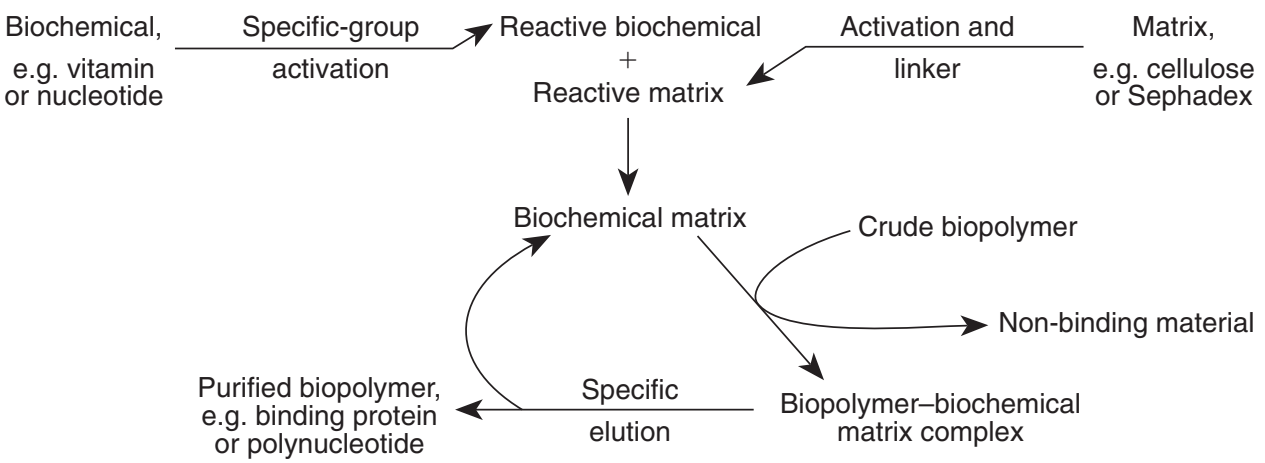

Fig. 5. Biochemically specific ('affinity') absorbents. By attaching a compound that specifically binds a biopolymer to an insoluble matrix in such a manner that allows separation from extraneous materials followed by elution of the biopolymer, purification of the latter can be achieved. 


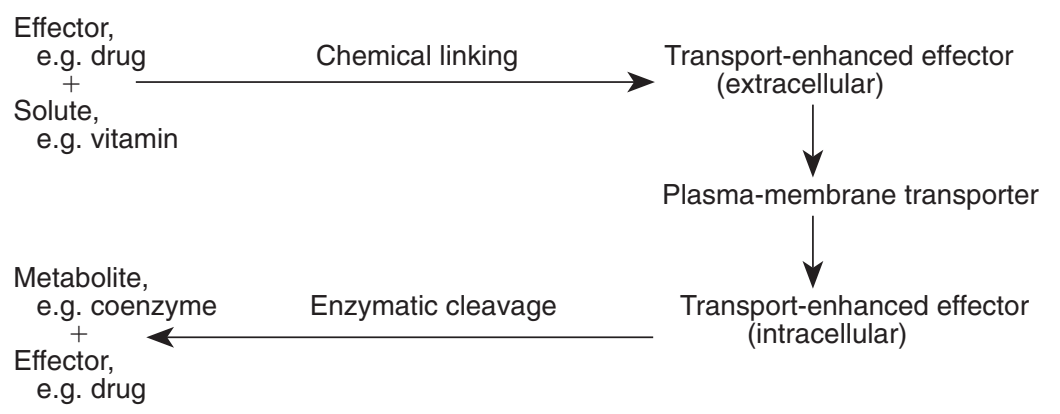

Fig. 6. Transporter-enhanced delivery of bioactive compounds. By attaching a less transportable compound, such as a poorly soluble drug, to a compound that gains facilitated entry and metabolic release within cells, transport of the less transportable compound into such cells can be enhanced.

1979a,b; Tsuge \& McCormick, 1980; Choi \& McCormick, 1981; Nakano et al. 1992; Nakano \& McCormick, 1992) and photochemical (McCormick et al. 1967; Koster et al. 1968; McCormick, 1968b, 1970; Tu \& McCormick, 1973) modifications of enzymes or, for that matter, any biopolymer.

\section{Pathogen photoinactivation}

A technique that is being developed for producing pathogen-free blood components is to take advantage of the photochemistry that is obtained with riboflavin and the fact that erythrocytes, platelets and plasma contain no nucleic acid. When this vitamin is irradiated with light at wavelengths that are in the visible range (and hence is not absorbed by simple proteins), the flavin excited state can interact with nucleic acids contained within viral and bacterial pathogens to effect photo-oxidation, especially of guanine residues, to cause killing of such organisms. The side-chain photoproducts of riboflavin that result are mainly those that we have shown are excreted in urine (Chastain \& McCormick, 1987a,b, 1988) and are secreted in milk from cows (Roughead \& McCormick, 1990a) and human subjects (Roughead \& McCormick, 1990b). Fig. 7 summarizes the process of photoinactivation using riboflavin.

\section{Dietary recommendations}

Our quantification of vitamins and their metabolites in the urine of human subjects has been helpful in assessment of losses that should be replaced in the diet. This has been the case for riboflavin (Chastain \& McCormick, 1987b, 1988) and biotin (Zempleni et al.1996e). Also knowledge of the secretion of flavins in human milk (Roughead \& McCormick, 1990b) aids in the estimation of an adequate allowance of riboflavin for infants, just as knowledge of flavin content of cows' milk allows us to estimate the contribution of this important source to our recommended dietary allowance such as periodically published in the US (Food and Nutrition Board and Institute of Medicine, 1998) with counterparts in other countries.

There has been good progress in unravelling the nature of micronutrient cofactors up to the present. Undoubtedly more can and should be learned in future research by others. 


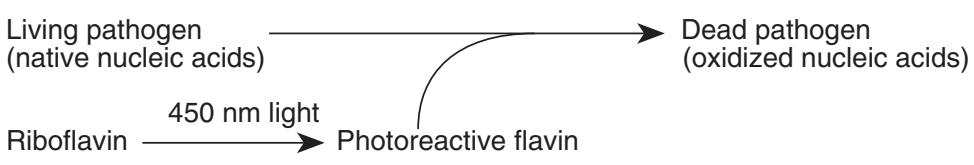

Fig. 7. Pathogen eradication by photoactivation of riboflavin. Because riboflavin can absorb light in the visible region to become a photoreactive oxidant for such bases as guanine within nucleic acids of bacteria and viruses, it can lead to destruction of pathogens within cells and fluids that have no nucleic acids.

\section{Acknowledgements}

I am grateful to my co-workers, most, but not all, of whom are listed in the references. Thanks are also due to the National Institutes of Health of the US Public Health Service, the Florida Citrus Association, and the Coca-Cola Research Foundation.

\section{References}

Addison R \& McCormick DB (1978) Biogenesis of flavoprotein and cytochrome components in hepatic mitochondria from riboflavin-deficient rats. Biochemical and Biophysical Research Communications 81, 133-138.

Arsenis C \& McCormick DB (1964a) Purification of liver flavokinase by column chromatography on flavin-cellulose compounds. Journal of Biological Chemistry 239, 3093-3097.

Arsenis C \& McCormick DB (1964b) Coenzyme specificity of NADPH-cytochrome c reductase for flavin phosphates. Biochimica et Biophysica Acta 92, 440-445.

Arsenis C \& McCormick DB (1966) Purification of flavin mononucleotide dependent enzymes by column chromatography on flavin phosphate cellulose compounds. Journal of Biological Chemistry 241, 330-334.

Aw T-Y, Jones DP \& McCormick DB (1983) Uptake of riboflavin by isolated rat liver cells. Journal of Nutrition 113, 1249-1254.

Bacher A, Eberhardt S, Fisher M, Kis K \& Richter G (2000) Biosynthesis of vitamin B (riboflavin). Annual Review of Nutrition 20, 153-167.

Bender DA (1992) Nutritional Biochemistry of the Vitamins. Cambridge: Cambridge University Press.

Bowers-Komro DM, Hagen TM \& McCormick DB (1986) Modified purification of pyridoxamine (pyridoxine) 5 '-phosphate oxidase from rabbit liver 5'-phosphopyridoxyl affinity chromatography. Methods in Enzymology 122, $116-120$.

Bowers-Komro DM \& McCormick DB (1984a) Mechanism and function of FMN in pyridoxine (pyridoxamine) 5'-phosphate oxidase. In Flavins and Flavoproteins, pp. 581-584 [RC Bray, PC Engel and SG Mayhew, editors]. New York: Walter de Gruyter.

Bowers-Komro DM \& McCormick DB (1984b) Steric restrictions in the active-site region of Liver pyridoxamine (pyridoxine) 5'-phosphate oxidase. In Chemical and Biological Aspects of Vitamin $B_{6}$ Catalysis, part A, pp. 387-396 [AE Evangelopoulos, editor]. New York: Alan R. Liss.

Bowers-Komro DM \& McCormick DB (1985a) Pyridoxamine 5'-phosphate oxidase exhibits no specificity in prochiral hydrogen abstraction from substrate. Journal of Biological Chemistry 260, 9580-9582.

Bowers-Komro DM \& McCormick DB (1985b) Biotin uptake by isolated rat liver hepatocytes. Annals of the New York Academy of Sciences 447, 350-358.

Bowers-Komro DM \& McCormick DB (1987) Single- and double-headed analogs of pyridoxamine 5'-phosphate as probes for pyridoxamine 5'-phosphate utilizing enzymes. Bioorganic Chemistry 15, 224-236.

Bowers-Komro DM, Yamada Y \& McCormick DB (1989) Substrate specificity and variables affecting efficiency of mammalian flavin adenine dinucleotide synthetase. Biochemistry 28, 8439-8446.

Bowman BB \& McCormick DB (1987) Pyridoxine uptake by proximal tubular epithelial cells isolated from rat kidney. In Biochemistry of Vitamin $B_{6}$, pp. 403-406 [T Korpela and P Christen, editors]. Basel: Birkhauser.

Bowman BB \& McCormick DB (1989) Pyridoxine uptake by rat renal proximal tubular cells. Journal of Nutrition 119, $745-749$.

Bowman BB, McCormick DB \& Rosenberg IH (1989) Epithelial transport of water-soluble vitamins. Annual Review of Nutrition 9, 187-199.

Brady RN, Li LF, McCormick DB \& Wright LD (1965) Bacterial and enzymatic degradation of biotin. Biochemical and Biophysical Research Communications 19, 777-778. 
Brady RN, Ruis H, McCormick DB \& Wright LD (1966) Bacterial degradation of biotin, catabolism of ${ }^{14}$ C-biotin and its sulfoxides. Journal of Biological Chemistry 241, 4717-4721.

Chang HH, Rozo ML \& McCormick DB (1975) Lipoate metabolism in Pseudomonas putida LP. Archives of Biochemistry and Biophyics 169, 244-251.

Chassy BM, Arsenis C \& McCormick DB (1965) The effect of the side chain of flavins on reactivity with flavokinase. Journal of Biological Chemistry 240, 1338-1340.

Chassy BM \& McCormick DB (1965a) Structural requirements of the moiety of flavin-adenine dinucleotide for intramolecular complex formation. Biochemistry 4, 2612-2615.

Chassy BM \& McCormick DB (1965b) Coenzyme specificity of D-amino acid oxidase for the flavin moiety of FAD Biochimica et Biophysica Acta 110, 91-96.

Chastain JL \& McCormick DB (1987a) Clarification and quantification of primary (tissue) and secondary (microbial) catabolites of riboflavin which are excreted in mammalian (rat) urine. Journal of Nutrition 117, 468-475.

Chastain JL \& McCormick DB (1987b) Flavin catabolites: Identification and quantitation in human urine. American Journal of Clinical Nutrition 46, 830-834.

Chastain JL \& McCormick DB (1988) Characterization of a new flavin metabolite from human urine. Biochimica et Biophysica Acta 967, 131-134.

Chen H \& McCormick DB (1997a) Riboflavin 5'-hydroxymethyl oxidation: Molecular cloning, expression and glycoprotein nature of the $5^{\prime}$-aldehyde forming enzyme from Schizophyllum commune. Journal of Biological Chemistry 272, 20077-20081

Chen H \& McCormick DB (1997b) Fungal riboflavin 5'-hydroxymethyl dehydrogenase catalyzes formation of both the aldehyde (riboflavinal) and the acid (riboflavinoic acid). Biochimica et Biophysica Acta 1342, 116-118.

Chia CP, Addison R \& McCormick DB (1978) Absorption, metabolism, and excretion of 8 $\alpha$-(amino acid)riboflavins in the rat. Journal of Nutrition 108, 373-381.

Choi JD, Bowers-Komro DM, Davis MD, Edmondson DE \& McCormick DB (1983) Kinetic properties of pyridoxine (pyridoxamine) 5' -phosphate oxidase from rabbit liver. Journal of Biological Chemistry 258, 840-845.

Choi JD, Davis MD, Bowers-Komro DM, Edmondson DE \& McCormick DB (1982) Steady-state kinetic properties of pyridoxamine (pyridoxine) 5'-phosphate oxidase from rabbit liver. In Flavins and Flavoproteins, pp. 208-212 [V Massey and CH Williams Jr, editors]. New York: Elsevier Biomedical.

Choi JD \& McCormick DB (1980) The interaction of flavins with egg white riboflavin-binding protein. Archives of Biochemistry and Biophysics 204, 41-51.

Choi JD \& McCormick DB (1981) Roles of arginyl residues in pyridoxamine (pyridoxine) $5^{\prime}$-phosphate oxidase from rabbit liver. Biochemistry 20, 5722-5728.

Combs GF Jr (1998) The Vitamins. Functional Aspects in Nutrition and Health, 2nd ed. San Diego: Academic Press.

DePecol ME \& McCormick DB (1980) Syntheses, properties, and use of fluorescent (N-5' -phospho-4'-pyridoxyl)amines in assay of pyridoxamine (pyridoxine) 5'-phosphate oxidase. Analytical Biochemistry 101, 435-441.

Falk MC, Johnson PG \& McCormick DB (1976) Synthetic flavinyl-peptides related to the active site of mitochondrial monoamine oxidase. I. Chemical and spectral properties. Biochemistry 15, 639-645.

Falk MC \& McCormick DB (1976) Synthetic flavinyl-peptides related to the active site of mitochondrial monoamine oxidase. II. Fluorescence properties. Biochemistry 15, 646-653.

Flint DH \& Allen RM (1997) Purification and characterization of biotin synthetases. Methods in Enzymology 279, 349-356.

Foley BA, MacKenzie RE \& McCormick DB (1967) Transport and storage of ${ }^{14} \mathrm{C}$-riboflavin in the retina and liver of rats. Proceedings of the Society for Experimental Biology and Medicine 126, 715-718.

Food and Nutrition Board and Institute of Medicine. Dietary Reference Intakes (1998) Washington, DC: National Academy Press.

Föry W, MacKenzie RE \& McCormick DB (1968) Flavinyl peptides. I. Syntheses of flavinyl-aromatic amino acids. Journal of Heterocyclic Chemistry 5, 625-630.

Föry W, MacKenzie RE, Wu FYH \& McCormick DB (1970a) Flavinyl peptides. II. Intra-molecular interactions in flavinyl-aromatic amino peptides. Biochemistry 8, 1839-1844.

Föry W, MacKenzie RE, Wu FYH \& McCormick DB (1970b) Flavinyl peptides. III. Studies of intramolecular interactions in flavinyl aromatic amino acids by proton magnetic resonance. Biochemistry 9, 515-525.

Froehlich JA, Merrill AH JR, Clagett CO \& McCormick DB (1980) Affinity chromatographic purification and comparison of riboflavin-binding proteins from laying hen liver and blood and from egg yolk. Comparative Biochemistry and Physiology 66B, 397-401.

Furr HC, Chang HH \& McCormick DB (1978) Lipoate metabolism in Pseudomonas putida LP: Thiolsulfinates of lipoate and bisnorlipoate. Archives of Biochemistry and Biophysics 185, 576-583.

Furr HC \& McCormick DB (1978) Bacterial catabolism of lipoic acid. Isolation and identification of a methyl ketone. International Journal of Vitamin and Nutrition Research 48, 68-71.

Getoff N, Solar S \& McCormick DB (1978) Photoejection of electrons from flavins in polar media. Science 201, 616-618.

Gomes B \& McCormick DB (1983) Purification and general characterization of FAD synthetase from rat liver. Proceedings of the Society for Experimental Biology and Medicine 172, 250-254.

Griesser R, Hayes MG, McCormick DB, Prijs B \& Sigel H (1971) $\mathrm{Mn}^{2+}, \mathrm{Cu}^{2+}$, and $\mathrm{Zn}^{2+} 1: 1$ complexes with biochemically significant thioether carboxylic acids and the sulfoxide and sulfone derivatives. Archives of Biochemistry and Biophysics 144, 628-635. 
Griesser R, Prijs B, Sigel H, Föry W, Wright LD \& McCormick DB (1970) Stability and structure of binary and ternary metal ion complexes with biocytin, the sulfoxide and sulfone, $\mathrm{N}-\alpha$-acetyl-L-lysine and L-alanine. Biochemistry 9, 3285-3293.

Griesser R, Prijs B, Sigel H \& McCormick DB (1969) Binary and ternary $\mathrm{Me}^{2+}$ complexes with $\alpha$ - or $\beta$-substituted halogeno carboxylic acids. Inorganic and Nuclear Chemistry Letters 5, 951-956.

Griesser R, Sigel H, Wright LD \& McCormick DB (1973) Interactions of metal ions with biotin and biotin derivatives. Complexing and hydrogen-bond formation of the ureido group. Biochemistry 12, 1917-1922.

Harrison EH \& McCormick DB (1974) The metabolism of $d l-\left[1,6-{ }^{14} \mathrm{C}\right]$ lipoic acid in the rat. Archives of Biochemistry and Biophysics 160, 514-522.

Horiike K \& McCormick DB (1979) Correlations between biological activity and the number of functional groups chemically modified. Journal of Theoretical Biology 79, 381-403.

Horiike K \& McCormick DB (1980) Effect of ligand on chemical modification of proteins. Graphical determinations of dissociation constant and number of essential residues affected by ligand binding. Journal of Theoretical Biology 84, 691-708.

Horiike K, Merrill AH Jr \& McCormick DB (1979a) Activation and inactivation of rabbit liver pyridoxamine (pyridoxine) $5^{\prime}$-phosphate oxidase activity by urea and other solutes. Archives of Biochemistry and Biophysics 195, 325-335.

Horiike K, Tsuge H \& McCormick DB (1979b) Evidence for an essential histidyl residue at the active site of pyridoxamine (pyridoxine) 5'-phosphate oxidase from rabbit liver. Journal of Biological Chemistry 254, 6638-6643.

Howard SC \& McCormick DB (1981) High-performance liquid chromatography of lipoic acid and analogues. Journal of Chromatography 208, 129-131.

Im WB, McCormick DB \& Wright LD (1973) Bacterial degradation of biotin. Isolation and identification of $d$-allobisnorbiotin. Journal of Biological Chemistry 248, 7798-7805.

Im WB, Roth JA, McCormick DB \& Wright LD (1970) Bacterial degradation of biotin. V. Metabolism of ${ }^{14}$ C-carbonyllabeled biotin $d$-sulfoxide. Journal of Biological Chemistry 245, 6269-6273.

Innis WSA, McCormick DB \& Merrill AH Jr (1985) Variations in riboflavin binding by human plasma: Identification of immunoglobulins as the major proteins responsible. Biochemical Medicine 34, 151-165.

Innis WSA, Nixon DW, Murray DR, McCormick DB \& Merrill AH Jr (1986) Immunoglobulins associated with elevated riboflavin binding by plasma from cancer patients. Proceedings of the Society for Experimental Biology and Medicine 181, 237-241.

Iwahara S, McCormick DB, Wright LD \& Li HC (1969) Bacterial degradation of biotin. III. Metabolism of ${ }^{14} \mathrm{C}$-carbonyl-labeled biotin. Journal of Biological Chemistry 244, 1393-1398.

Johnson PG, Bell AP \& McCormick DB (1975) Flavin-sensitized photooxidation of histidine. Photochemistry and Photobiology 21, 205-208.

Johnson PG \& McCormick DB (1973) Syntheses and properties of flavin-histidine peptides. Biochemistry 12, 3359-3364.

Joseph T, Tsuge H, Suzuki Y \& McCormick DB (1996) Uptake and metabolism of pyridoxine 4'- $\alpha-$ and $55^{\prime}-\beta-D-$ glucosides by isolated rat liver cells. Journal of Nutrition 126, 2899-2903.

Kazarinoff MN, Arsenis C \& McCormick DB (1975) Preparation of FMN-cellulose and derivatives and FMN-agarose. Methods in Enzymology 34B, 300-302.

Kazarinoff MN, Im WB, Roth JA, McCormick DB \& Wright LD (1972) Bacterial degradation of biotin. VI. Isolation and identification of ß-hydroxy and B-keto compounds. Journal of Biological Chemistry 247, 75-83.

Kazarinoff MN \& McCormick DB (1973) N-(5'-Phospho-4'-pyridoxyl)amines as substrates for pyridoxine (pyridoxamine) 5'-phosphate oxidase. Biochemical and Biophysical Research Communications 52, 440-446.

Kazarinoff MN \& McCormick DB (1974) Specificity of pyridoxine (pyridoxamine) 5'-phosphate oxidase for flavinphosphates. Biochimica et Biophysica Acta 359, 282-287.

Kazarinoff MN \& McCormick DB (1975) Rabbit liver pyridoxamine (pyridoxine) 5'-phosphate oxidase: Purification and properties. Journal of Biological Chemistry 250, 3436-3442.

Kekelidze TN, Edmondson DE \& McCormick DB (1994) Flavin substrate specificity of the vitamin $\mathrm{B}_{2}$-aldehyde-forming enzyme from Schizophyllum commune. Archives of Biochemistry and Biophysics 315, 100-103.

Kekelidze TN, Edmondson DE \& McCormick DB (1995) Preparation of riboflavin specifically labeled in the 5'-hydroxymethyl terminus using a $\mathrm{B}_{2}$-aldehyde-forming enzyme from Schizophyllum commune. Journal of Labelled Compounds and Radiopharmaceuticals XXXVI, 953-960.

Koster JF, Veeger C \& McCormick DB (1968) Photoreduction of amino acid oxidases in the presence of free flavin and the effect of urea. Biochimica et Biophysica Acta 153, 724-726.

Kozik A \& McCormick DB (1984) Mechanism of pyridoxine uptake by isolated rat liver cells. Archives of Biochemistry and Biophysics 229, 187-193

Lee HM, McCall NE, Wright LD \& McCormick DB (1973a) Urinary excretion of biotin and metabolites in the rat. Proceedings of the Society for Experimental Biology and Medicine 143, 642-644.

Lee HM, Wright LD \& McCormick DB (1972) The metabolism of carbonyl-labeled ${ }^{14}$ C-biotin in the rat. Journal of Nutrition 102, 1453-1464.

Lee HM, Wright LD \& McCormick DB (1973b) Metabolism, in the rat, of biotin injected intraperitoneally as the avidin-biotin complex. Proceedings of the Society for Experimental Biology and Medicine 143, 438-442.

Lee S-S \& McCormick DB (1983) Effect of riboflavin status on hepatic activities of flavin-metabolizing enzymes in rats. Journal of Nutrition 113, 2274-2279. 
Lee S-S \& McCormick DB (1985) Thyroid hormone regulation of flavocoenzyme biosynthesis. Archives of Biochemistry and Biophysics 237, 197-201.

Li HC, McCormick DB \& Wright LD (1968a) Conversion of dethiobiotin to biotin in Aspergillus niger. Journal of Biological Chemistry 243, 6442-6445.

Li HC, McCormick DB \& Wright LD (1968b) Metabolism of dethiobiotin in Aspergillus niger. Journal of Biological Chemistry 243, 4391-4395.

McCormick DB (1961) Flavokinase of rat tissues and masking effect of phophatases. Proceedings of the Society for Experimental Biology and Medicine 107, 784-786.

McCormick DB (1962) The intracellular localization, partial purification, and properties of flavokinase from rat liver. Journal of Biological Chemistry 237, 959-962.

McCormick DB (1964a) Specificity of flavin-adenine dinucleotide pyrophosphorylase for flavin phosphates and nucleotide triphosphates. Biochemical and Biophysical Research Communications 14, 493-497.

McCormick DB (1964b) Inhibition of flavin-adenine dinucleotide pyrophosphorylase by isoriboflavin. Nature 201, 925-926.

McCormick DB (1965) Specific purification of avidin by column chromatography on biotin-cellulose. Analytical Biochemistry 13, 194-198.

McCormick DB (1968a) Nature of the intramolecular complex of flavine adenine di-nucleotide. In Molecular Associations in Biology, pp. 377-392 [D Pullman, editor]. New York: Academic Press.

McCormick DB (1968b) Photochemical reactions of FAD and FAD-dependent flavoproteins. In Flavins and Flavin Enzymes, pp. 154-163 [K Yagi, editor]. Tokyo: University of Tokyo Press.

McCormick DB (1969) Chemical syntheses and biocytinase specificity for sulfoxides and sulfone of $d$-biotin. Proceedings of the Society for Experimental Biology and Medicine 132, 502-504.

McCormick DB (1970) The tryptophans in flavodoxin and synthetic flavinyl peptides characterized by chemical and photochemical oxidations. Experientia 26, 243-244.

McCormick DB (1975a) Biotin. Nutrition Reviews 33, 97-102.

McCormick DB (1975b) Metabolism of riboflavin. In Riboflavin, pp. 153-198 [RS Rivlin, editor]. New York: Plenum Press.

McCormick DB (1976a) Riboflavin. In Present Knowledge in Nutrition, 4th ed., pp. 131-140 [DM Hegsted, editor] New York: The Nutrition Foundation.

McCormick DB (1976b) Biotin. In Present Knowledge in Nutrition, 4th ed., pp. 217-225 [DM Hegsted, editor]. New York: The Nutrition Foundation.

McCormick DB (1977a) Interactions of flavins with amino acid residues: Assessments from spectral and photochemical studies. Photochemistry Photobiology 26, 169-182.

McCormick DB (1977b) Spectral and photochemical assessments of interactions of the flavin ring system with amino acid residues. In 10th Jerusalem Symposium: Excited States in Organic Chemistry and Biochemistry, pp. 233-245 [B Pullman and N Goldblum, editors]. Dordrecht: Reidel Publishing Co.

McCormick DB (1989) Application of new techniques in nutrition research: An example with riboflavin. In Nutrition, Health Promotion, and Chronic Disease Prevention: International Perspective, pp. 555-563 [S Palmer, FM Peter, S Eckhardt and Z Schoket, editors]. Budapest: Skala.

McCormick DB (1994) Vitamin $\mathrm{B}_{6}$ transport and metabolism: Clues for delivery of bio-active compounds. In Biochemistry of Vitamin B and PQQ, pp. 311-317 [G Marino, G Sannia and F Bossa, editors]. Basel: Birkhauser.

McCormick DB (2000) A trail of research on cofactors: An odyssey with friends. Journal of Nutrition 130, 323S-330S.

McCormick DB (2001) Vitamin B-6. In Present Knowledge in Nutrition, 8th ed., pp. 207-213 [BA Bowman and RM Russell, editors]. Washington, DC: ILSI Press.

McCormick DB, Arsenis C \& Hemmerich P (1963) Specificity of liver flavokinase for 9-(1'-D-ribityl)isoalloxazines variously substituted in positions 2, 6 and 7. Journal of Biological Chemistry 238, 3095-3099.

McCormick DB \& Bowers-Komro DM (1986) Stereochemistry of pyridoxamine 5' - phosphate oxidase. In Mechanisms of Enzymatic Reactions: Stereochemistry, p. 336 [PA Frey, editor]. New York: Elsevier.

McCormick DB, Bowers-Komro DM, Bonkovsky J, Larson C \& Zhang Z (1991) Characteristics of a transporter for uptake of vitamin $\mathrm{B}_{6}$ into mammalian cells. In Enzymes Dependent on Pyridoxal Phosphate and Other Carbonyl Compounds as Cofactors, pp. 609-611 [T Fukui, H Kagamiyama, K Soda \& H Wada, editors]. New York: Pergamon Press.

McCormick DB \& Butler RC (1962) Substrate specificity of liver flavokinase. Biochimica et Biophysica Acta 65, 326-332.

McCormick DB, Chassy BM \& Tsibris JCM (1964) Coenzyme specificity of D-amino acid oxidase for the adenylate moiety of FAD. Biochimica et Biophysica Acta 89, 447-452.

McCormick DB \& Chen H (1999) Update on interconversions of vitamin B-6 with its co-Enzyme. Journal of Nutrition 129, 325-327.

McCormick DB, Falk MC, Rizzuto F \& Tollin G (1975) Inter- and intramolecular effects of tyrosyl residues on flavin triplets and radicals as investigated by flash photolysis. Photochemistry and Photobiology 22, 175-182.

McCormick DB, Gregory ME \& Snell EE (1961) Pyridoxal phosphokinases. I. Assay, distribution, purification, and properties. Journal of Biological Chemistry 236, 2076-2084.

McCormick DB, Griesser R \& Sigel H (1974) Metal ion-thioether interactions of biological interest. In Metal Ions in Biological Systems, vol. 1, pp. 213-246 [H Sigel, editor]. New York: Marcel Dekker 
McCormick DB, Guirard BM \& Snell EE (1960) Comparative inhibition of pyridoxal kinase and glutamic acid decarboxylase by carbonyl reagents. Proceedings of the Society for Experimental Biology and Medicine 104, 554-557.

McCormick DB, Innis WSA, Merrill AH Jr, Bowers-Komro DM, Oka M \& Chastain JL (1988) An update on flavin metabolism in rats and humans. In Flavins and Flavoproteins, pp. 459-471 [DE Edmondson and DB McCormick, editors]. New York: Walter de Gruyter.

McCormick DB, Innis WJA, Merrill AH Jr \& Lee S-S (1984) Mammalian metabolism of flavins. In Flavins and Flavoproteins, pp 833-846 [RC Grey, PC Engel and SG Mayhew, editors]. New York: Walter de Gruyten.

McCormick DB, Kazarinoff MN \& Tsuge H (1976) FMN-dependent pyridoxine (pyridoxamine) 5'-phosphate oxidase from rabbit liver. In Flavins and Flavoproteins, pp. 708-719 [TP Singer, editor]. New York: Walter de Gruyter.

McCormick DB, Koster JF \& Veeger C (1967) On the mechanisms of photochemical reductions of FAD and FADdependent enzymes. European Journal of Biochemistry 2, 387-391.

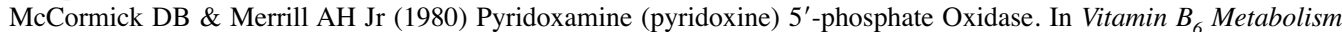
and Role in Growth, pp. 1-26 [GP Tryfiates, editor]. Westport, CT: Food and Nutrition Press.

McCormick DB, Oka M, Bowers-Komro DM, Yamada Y \& Hartman H (1997a) Purification and properties of FAD synthetase from liver. Methods in Enzymology 280J, 407-413.

McCormick DB \& Olson RE (1984) Biotin. In Present Knowledge in Nutrition, 5th ed., pp. 365-376 [RE Olson, editor]. Washington, DC: The Nutrition Foundation.

McCormick DB \& Roth JA (1970) Specificity, stereochemistry and mechanism of the colour reaction between p-dimethylaminocinnamaldehyde and biotin analogues. Analytical Biochemistry 34, 226-236.

McCormick DB \& Russell M (1962) Hydrolysis of flavin mononucleotide by acid phosphatases from animal tissues. Comparative Biochemistry and Physiology 5, 113-121.

McCormick DB, Sigel H \& Wright LD (1969) Structure of $\mathrm{Mn}^{2+}$ and $\mathrm{Cu}^{2+}$ complexes with L-methionine, S-methyl-Lcysteine, L-threonine, and L-serine. Biochimica et Biophysica Acta 184, 318-328.

McCormick DB \& Snell EE (1959) Pyridoxal kinase of human brain and its inhibition by hydrazine derivatives Proceedings of the National Academy of Sciences, 45, 1371-1379.

McCormick DB \& Snell EE (1961) Pyridoxal phosphokinases. II. Effects of inhibitors. Journal of Biological Chemistry 236, 2085-2088.

McCormick DB, Suttie JW \& Wagner C (editors) (1997b) Vitamins and Coenzymes. Methods in Enzymology, vols. 279, 280, 281, 282. Orlando, FL: Academic Press.

McCormick DB \& Tu SC (1970) Colorimetric determination of tyrosine in the presence of flavin. Analytical Biochemistry 37, 215-219.

McCormick DB \& Wright LD (1970) The metabolism of biotin and its analogues. In Comprehensive Biochemistry, vol. 21,pp. 81-110 [M Florkin and EH Stotz, editors]. Amsterdam: Elsevier.

MacKenzie RE, Föry W \& McCormick DB (1969) Flavinyl peptides. II. Intramolecular interactions in flavinylaromatic amino acid peptides. Biochemistry 8, 1839-1844.

Merrill AH Jr, Addison R \& McCormick DB (1978a) Induction of hepatic and intestinal flavokinase after oral administration of riboflavin to riboflavin-deficient rats. Proceedings of the Society for Experimental Biology and Medicine 158, 572-574.

Merrill AH Jr, Froehlich JA \& McCormick DB (1979a) Purification of riboflavin- binding proteins from bovine plasma and discovery of a pregnancy-specific riboflavin-binding protein. Journal of Biological Chemistry 254, 9362-9364.

Merrill AH Jr, Froehlich JA \& McCormick DB (1981a) Isolation and identification of alternative riboflavin-binding proteins from human plasma. Biochemical Medicine 25, 198-206.

Merrill AH Jr, Horiike K \& McCormick DB (1978b) Evidence for the regulation of pyridoxal 5'-phosphate formation in liver by pyridoxamine (pyridoxine) 5'-phosphate oxidase. Biochemical and Biophysical Research Communications 83, 984-990.

Merrill AH Jr, Kasai S, Matsui K, Tsuge H \& McCormick DB (1979b) Spectroscopic studies of pyridoxamine (pyridoxine) 5'-phosphate oxidase. Equilibrium dissociation constants and spectra for riboflavin $5^{\prime}$-phosphate and analogs. Biochemistry 18, 3635-3641.

Merrill AH Jr, Korytnyk W, Horiike K \& McCormick DB (1980) Spectroscopic studies of complexes between pyridoxamine (pyridoxine) 5' -phosphate oxidase and pyridoxyl 5'-phosphate compounds differing at position $4^{\prime}$. Biochimica et Biophysica Acta 626, 57-63.

Merrill AH Jr, Lambeth JD, Edmondson DE \& McCormick DB (1981b) Formation and mode of action of flavoproteins. Annual Review of Nutrition 1, 281-317.

Merrill AH Jr \& McCormick DB (1978) Flavin affinity chromatography: General methods for purification of proteins that bind riboflavin. Analytical Biochemistry 89, 87-102.

Merrill AH Jr \& McCormick DB (1979) Preparation and properties of immobilized flavokinase. Biotechnology and Bioengineering XXI, 243-252.

Merrill AH Jr \& McCormick DB (1980) Affinity chromatographic purification and properties of flavokinase (ATP: riboflavin 5'-phosphotransferase) from rat liver. Journal of Biological Chemistry 255, 1335-1338.

Merrill AH Jr, Shapira G \& McCormick DB (1982) Recent findings concerning mammalian riboflavin-binding proteins. In Flavins and Flavoproteins, pp. 508-513 [V Massey and CH Williams Jr, editors]. New York: Elsevier Biomedical.

Nakano H, Hartman H \& McCormick DB (1992) Mammalian flavokinase and FAD synthetase: Functions of divalent 
metal ions and arginyl residues in the anionic substrate sites. In 1st International Congress on Vitamins and Biofactors in Life Science, pp. 450-452 [T Kobayashi, editor]. Osaka: Center for Academic Publications.

Nakano H \& McCormick DB (1991a) Rat brain flavokinase: purification, properties, and comparison to the enzyme from liver and small intestine. In Flavins and Flavoproteins, pp. 89-92 [B Curti, S Ronchi and G Zanetti, editors]. New York: Walter de Gruyter.

Nakano H \& McCormick DB (1991b) Stereospecificity of the metal-ATP complex in flavokinase from rat small intestine. Journal of Biological Chemistry 266, 22125-22128.

Nakano H \& McCormick DB (1992) Modification of arginyl and lysyl residues in flavo-kinase from rat small intestine. Biochemistry International 28, 441-450.

Ogunmodede BK \& McCormick DB (1966) Sparing of riboflavin in rats by 6,7-dimethyl-9-( $\omega$-hydroxyalkyl)isoalloxazines. Proceedings of the Society for Experimental Biology and Medicine 122, 845-847.

Oka M \& McCormick DB (1985) Urinary lumichrome-level catabolites of riboflavin are due to microbial and photochemical events and not tissue enzymic cleavage of the ribityl chain. Journal of Nutrition 115, 496-499.

Oka M \& McCormick DB (1987) Complete purification and general characterization of FAD synthetase from rat liver. Journal of Biological Chemistry 262, 7418-7422.

Pritchard AB, McCormick DB \& Wright LD (1967) Optical rotatory dispersion studies on the heat denaturation of avidin and the avidin-biotin complex. Biochemical and Biophysical Research Communications 25, 524-528.

Rasmussen KM, Barsa PM, \& McCormick DB (1979) Pyridoxamine (pyridoxine) 5'-phosphate oxidase activity in rat tissues during development of riboflavin or pyridoxine deficiency. Proceedings of the Society for Experimental Biology and Medicine 161, 527-530.

Rasmussen KM, Barsa PM, McCormick DB \& Roe DA (1980) Effect of strain, sex and dietary riboflavin on pyridoxamine (pyridoxine) 5'-phosphate oxidase activity in rat tissues. Journal of Nutrition 110, 1940-1946.

Roth JA, Chassy BM \& McCormick DB (1966) Coenzymatic activities of 2-anilino and 2-morpholino derivatives of FMN with yeast NADPH diaphorase. Biochimica et Biophysica Acta 118, 429-431.

Roth JA \& McCormick DB (1967) Complexing of riboflavin and its 2-substituted analogues with adenosine and other 6-substituted purine derivatives. Photochemistry and Photobiology 6, 657-664.

Roth JA, McCormick DB \& Wright LD (1970) Bacterial degradation of biotin. IV. Metabolism of ${ }^{14} \mathrm{C}$-carbonyl-labeled biotin $l$-sulfoxide. Journal of Biological Chemistry 245, 6264-6268.

Roughead ZK \& McCormick DB (1990a) A qualitative and quantitative assessment of flavins in cows milk. Journal of Nutrition 120, 382-388.

Roughead ZK \& McCormick DB (1990b) Flavin composition of human milk. American Journal of Clinical Nutrition $\mathbf{5 2}, 854-857$.

Roughead ZK \& McCormick DB (1991) Urinary riboflavin and its metabolites: Effects of riboflavin supplementation in healthy residents of rural Georgia (USA). European Journal of Clinical Nutrition 45, 299-307.

Rucker RB, Suttie JW, McCormick DB \& Machlin LJ (editors) (2001) Handbook of Vitamins, 3rd ed. New York: Marcel Dekker.

Ruis H, Brady RN, McCormick DB \& Wright LD (1968) Bacterial degradation of biotin. II. Catabolism of ${ }^{14}$ C-homobiotin and ${ }^{14} \mathrm{C}$-norbiotin. Journal of Biological Chemistry 243, 547-551.

Sander EG, McCormick DB \& Wright LD (1966) Column chromatography of nucleotides over thymidylate-cellulose. Journal of Chromatography 21, 419-423.

Sander EG, Wright LD \& McCormick DB (1965) Evidence for function of metal ion in the activity of dihydroorotase from Zymobacterium oroticum. Journal of Biological Chemistry 240, 3628-3630.

Schneider G \& Lindqvist Y (1997) Structure of ATP-dependent carboxylase, dethiobiotin synthase. Methods in Enzymology 279, 376-385.

Shiga K, Tollin G, Falk MC \& McCormick DB (1975) Binding and oxidation-reduction of monoamine oxidase-type $8 \alpha$-(S-peptidyls) flavins with Azotobacter (Shethna) flavodoxin. Biochemical and Biophysical Research Communications 66, 227-234.

Shih JCH, Rozo ML, Wright LD \& McCormick DB (1975) Characterization of the growth of Pseudomonas putida LP on lipoate and its analogues: Transport, oxidation, sulphur source, and enzyme induction. Journal of General Microbiology 86, 217-227.

Shih JCH, Williams PB, Wright LD \& McCormick DB (1974) Properties of lipoic acid analogs. Journal of Heterocyclic Chemistry 11, 119-123.

Shih JCH, Wright LD \& McCormick DB (1972) Isolation, identification and characterization of a lipoate-degrading pseudomonad and of a lipoate catabolite. Journal of Bacteriology 112, 1043-1051.

Sigel H (editor) (1974) Metal Ions in Biological Systems, vol. 1, Simple complexes. New York: Marcel Dekker.

Sigel H, Becker K \& McCormick DB (1967) Ternary complexes in solution. Influence of 2,2'-bipyridyl on the stability of $1: 1$ complexes of $\mathrm{Co}^{2+}, \mathrm{Ni}^{2+}, \mathrm{Cu}^{2+}$, and $\mathrm{Zn}^{2+}$ with hydrogen phosphate, adenosine $5^{\prime}$-monophosphate, and adenosine 5'-triphosphate. Biochimica et Biophysica Acta 148, 655-664.

Sigel H, Griesser R \& McCormick DB (1969a) On the structure of manganese(II)- and copper(II)-histidine complexes. Archives of Biochemistry and Biophysics 134, 217-227.

Sigel H, Griesser R \& McCormick DB (1972) Ternary complexes in solution. XIII. Mixed-ligand complexes of copper(II) or zinc(II) with 2,2'-bipyridyl and thioether carboxylates or some of their sulfoxide or sulfone derivatives. Inorganica Chimica Acta 6, 559-563.

Sigel H, Griesser R , Prijs B, McCormick DB \& Joiner M (1969b) 'Hard and soft' behavior of $\mathrm{Mn}^{2+}, \mathrm{Cu}^{2+} \mathrm{and}^{2+}$ 
with respect to carboxylic acids and $\alpha$-oxy- or $\alpha$-thio-substituted carboxylic acids of biochemical significance Archives of Biochemistry and Biophysics 130, 514-520.

Sigel H \& McCormick DB (1971) The structure of the $\mathrm{Cu}^{2+}$ L-histidine 1:2 complex in solution. Journal of the American Chemical Society 93, 2041-2044.

Sigel H \& McCormick DB (1974) On the discriminating behavior of metal ions and ligands with regard to their biological significance. In Collected Accounts of Transition Metal Chemistry [JF Bunnett, editor]. Washington, DC: American Chemical Society.

Sigel H, McCormick DB, Griesser R, Prijs B \& Wright LD (1969c) Metal ion complexes with biotin and biotin derivatives. Participation of sulfur in the orientation of divalent cations. Biochemistry 8, 2687-2695.

Sigel H, MacKenzie RE \& McCormick DB (1970) On the structure of copper(II)-histidine complexes. Biochimica et Biophysica Acta 200, 411-413.

Sigel H, Neumann CF, Prijs B, McCormick DB \& Falk MC (1977) Influence of alkyl side chains with hydroxy or thioether groups on the stability of binary and ternary copper(II)-dipeptide complexes. Inorganic Chemistry 16, 790-796.

Sigel H, Prijs B \& McCormick DB (1978a) Stability and structure of $\mathrm{Cd}^{2+}$ and $\mathrm{Pb}^{2+}$ com-plexes with biotin, lipoic acid, and some of their derivatives in solution. Journal of Inorganic and Nuclear Chemistry 40, 1678-1680.

Sigel H, Prijs B, McCormick DB \& Shih JCH (1978b) Stability and structure of binary and ternary complexes of $\alpha$ lipoate and lipoate derivatives with $\mathrm{Mn}^{2+}, \mathrm{Cu}^{2+}$ and $\mathrm{Zn}^{2+}$ in solution. Archives of Biochemistry and Biophysics $\mathbf{1 8 7}$ 208-214.

Spence JT \& McCormick DB (1976) Lipoic acid metabolism in the rat. Archives of Biochemistry and Biophysics 174, 13-19.

Tepper JP, McCormick DB \& Wright LD (1966) Direct evidence for the conversion of dethiobiotin to biotin in Aspergillus niger. Journal of Biological Chemistry 241, 5734-5735.

Tsibris JCM, McCormick DB \& Wright LD (1965) Studies on the donor-acceptor complexes relating to the intramolecular association of the riboflavin and adenosine moieties of flavin-adenine dinucleotide. Biochemistry 4, 504-509.

Tsibris JCM, McCormick DB \& Wright LD (1966) Studies on the binding and function of flavin phosphates with flavin mononucleotide-dependent enzymes. Journal of Biological Chemistry 241, 1138-1143.

Tsuge H \& McCormick DB (1980) Reactivity of the sulfhydryl groups in pyridoxamine phosphate oxidase from liver. In Flavins and Flavoproteins, pp. 517-527 [K Yagi and T Yamano, editors]. Tokyo: Japan Scientific Society Press.

Tu SC \& McCormick DB (1969) The biological activity and excretion of 6,7-dimethyl- 9-( $\omega$-carboxyalkyl)isoalloxazines in rats. Journal of Nutrition 97, 307-310.

Tu SC \& McCormick DB (1972) Insolubilized D-amino acid oxidase: Properties and potential use. Separation Science 7, 403-407.

Tu SC \& McCormick DB (1973) Photoinactivation of porcine D-amino acid oxidase with flavin-adenine dinucleotide. Journal of Biological Chemistry 248, 6339-6347.

Tu SC \& McCormick DB (1974) Conformation of porcine D-amino acid oxidase as studied by protein fluorescence and optical rotatory dispersion. Biochemistry 13, 893-899.

Visser J, McCormick DB \& Veeger C (1968) Relation between conformation and activities of lipoamide dehydrogenase. II. Some aspects of recombination with FAD analogues. Biochimica et Biophysica Acta 159, 257-264.

Walker FA, Sigel H \& McCormick DB (1972) Spectral properties of mixed-ligand copper(II) complexes and their corresponding binary parent complexes. Inorganic Chemistry 11, 2756-2763.

Westendorf J \& McCormick DB (1980) Isolation of volatile sulfur-containing microbial catabolites of biotin. International Journal of Vitamin and Nutrition Research 50, 62-65.

Winkler ME (2000) Genetic and genomic approaches for delineating the pathway of pyridoxal 5'-phosphate coenzyme biosynthesis in Escherichia coli. In Biochemistry and Molecular Biology of Vitamin $B_{6}$ and PQQ-dependent Proteins, pp. 3-10 [A Iriarte, HM Kagan and M Martinez-Carrion, editors]. Basel: Birkhauser.

Wu FYH \& McCormick DB (1971a) The fluorescence quenching of aromatic amino acids and flavin portions of flavinyl peptides. Biochimica et Biophysica Acta 229, 440-443.

Wu FYH \& McCormick DB (1971b) Flavin-sensitized photooxidations of tryptophan and tyrosine. Biochimica et Biophysica Acta 236, 479-483.

Wu FYH, Tu SC, Wu WC \& McCormick DB (1970) Characteristics of the fluorescence spectra of apoenzyme and flavin portions of D-amino acid oxidase. Biochemical and Biophysical Research Communications 41, 381-385.

Yamada Y, Merrill AH Jr \& McCormick DB (1990) Probable reaction mechanisms of flavokinase and FAD synthetase from rat liver. Archives of Biochemistry and Biophysics 278, 125-130.

Yang CS, Arsenis CS \& McCormick DB (1964) Microbiological and enzymatic assays of riboflavin analogues. Journal of Nutrition 84, 167-172.

Yang CS \& McCormick DB (1967a) Substrate specificity of riboflavin hydrolase from Pseudomonas riboflavina. Biochimica et Biophysica Acta 132, 511-513.

Yang CS \& McCormick DB (1967b) Degradation and excretion of riboflavin in the rat. Journal of Nutrition 93, 445-453.

Zempleni J, Galloway JR \& McCormick DB (1996a) Pharmacokinetics of orally and intravenously administered riboflavin in healthy humans. American Journal of Clinical Nutrition 63, 54-66.

Zempleni J, Galloway JR \& McCormick DB (1996b) The identification and kinetics of $7 \alpha$-hydroxyriboflavin 
(7-hydroxymethylriboflavin) in blood plasma from humans following oral administration of riboflavin supplements. International Journal of Vitamin and Nutrition Research 66, 151-157.

Zempleni J, Galloway JR \& McCormick DB (1996c) The metabolism of riboflavin in female patients with liver cirrhosis. International Journal of Vitamin and Nutrition Research 66, 237-243.

Zempleni J, McCormick DB \& Mock DM (1996d) The identification of biotin sulfone, bisnorbiotin methyl ketone, and tetranorbiotin- $l$-sulfoxide in human urine. American Journal of Clinical Nutrition $\mathbf{6 5}, 508-511$.

Zempleni J, McCormick DB, Stratton SL \& Mock DB (1996e) Lipoic acid (thioctic acid) analogs, tryptophan analogs, and urea do not interfere with the assay of biotin and biotin metabolites by high-performance liquid chromatography/avidin-binding assay. Journal of Nutritional Biochemistry 7, 518-523.

Zhang Z, Gregory J E III \& McCormick DB (1993a) Uptake and metabolism of pyridoxine-5'- $\beta$-D-glucoside by isolated rat liver cells. Journal of Nutrition 123, 85-89.

Zhang Z \& McCormick DB (1991) Uptake of N-(4'-pyridoxyl)amines and release of amines by renal cells: A model for transporter-enhanced delivery of bioactive compounds. Proceedings of the National Academy of Sciences, 88, $10407-10410$.

Zhang Z \& McCormick DB (1992a) Uptake and metabolism of N-(4'-pyridoxyl)amines by isolated rat liver cells. Archives of Biochemistry and Biophysics 294, 394-397.

Zhang Z \& McCormick DB (1992b) Uptake and metabolism of 4' N-substituted pyridoxamines by cells from the liver and kidneys of rats. In 1st International Congress on Vitamin and Biofactors in Life Science, pp. 208-211 [T Kobayashi, editor]. Osaka: Center for Academic Publications.

Zhang Z, Smith E, Surowiec SM, Merrill AH Jr \& McCormick DB (1993b) Synthesis of N-(4'-pyridoxyl)-sphingosine and its uptake and metabolism by isolated cells. Membrane Biochemistry 10,53-59. 